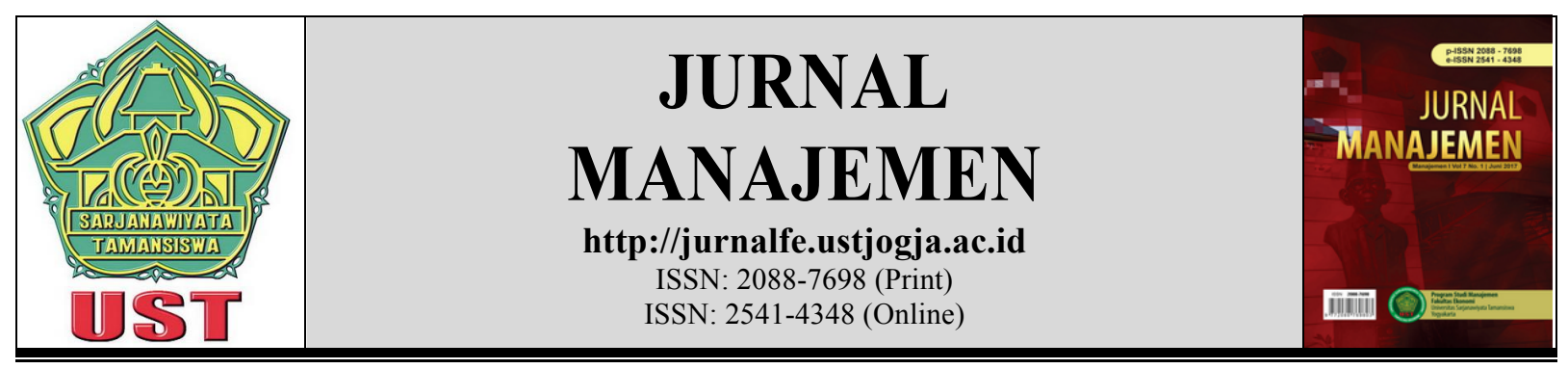

\title{
RISIKO LIKUIDITAS DAN DETERMINANNYA: STUDI EMPIRIS PADA BANK SWASTA NASIONAL DEVISA DI INDONESIA
}

\section{Perminas Pangeran}

Fakultas Bisnis, Universitas Kristen Duta Wacana

Korespondensi: perminas@staff.ukdw.ac.id

\begin{tabular}{ll}
\hline Informasi Naskah & \multicolumn{1}{c}{ Abstrak } \\
\hline Diterima: & The purpose of this study is to examine the influence of bank's \\
10 November 2017 & characteristics on liquidity risk in the case of 22 out of 35 \\
Revisi: & commercial banks in Indonesia, by using data in the period 2010- \\
12 Desember 2017 & 2015. The results show some important things. First, \\
Terbit: & Capitalization has a positive effect on liquidity risk. Second, cash \\
19 Desember 2017 & reserves and loan to deposit ratio also negatively affect liquidity \\
\hline Kata Kunci: Liquidity & risk. These results are supported by both proxies for liquidity risk, \\
Risk, Bank's & i.e. liquid assets to total assets and liquid assets to customer \\
Characteristics & deposits and short-term funding. Third, the fifth characteristics of \\
& other banks, namely non-performing loans, size, profitability, loss \\
& loan reserve, no effect on liquidity risk.
\end{tabular}

\section{PENDAHULUAN}

Menanggapi krisis 2007, Komite Basel mengusulkan sebuah peraturan baru untuk menghadapi risiko sistematis bank, termasuk risiko likuiditas untuk mencegah kebangkrutan Bank. Krisis ini telah menyoroti kelemahan dalam pengelolaan risiko likuiditas oleh bank-bank, yang mengalami kekurangan likuiditas (Zaghdoudi and Hakimi, 2017). Risiko likuiditas adalah salah satu persoalan yang harus dihadapi bank (Jenkinson 2008). Kegagalan kebanyakan bank menunjukkan bahwa para manajer bank belum mengevaluasi risiko likuiditas atau belum mengatasinya dengan baik.

Masalah likuiditas menjadi penting bagi bank, ketika banyak masyarakat kehilangan kepercayaan pada sistem perbankan yang ada. Namun, mempertahankan posisi dan pengelolaan risiko likuiditas defensif adalah sangat menantang dan sulit. Tantangan ini terjadi terutama dalam sistem ekonomi kompetitif dan terbuka dengan pengaruh eksternal yang kuat dan pemain pasar yang sensitif (Siddiqi 2008). Bank yang sukses dan terorganisir dengan baik harus memiliki sistem yang stabil tidak hanya untuk evaluasi tetapi juga untuk pengelolaan risiko 
likuiditas. Meskipun risiko likuiditas bank memiliki peran penting, namun demikian kajian masih belum mendalam tentang risiko likuiditas Bank.

Selama periode 2010 hingga 2014, kondisi likuiditas bank-bank yang terdaftar di Bursa Efek Indonesia yang menjadi objek penelitian mengalami penurunan. Pada tahun 2010, proporsi rata-rata aset lancar bank terhadap total asetnya adalah sebesar $23,51 \%$, namun dalam periode lima tahun mengalami penurunan, dan pada tahun 2014 rasionya hanya sebesar $18,27 \%$. Penurunan juga dapat terlihat pada rasio aset lancar atas total deposito, dimana pada tahun 2010 mencapai 27,81\%, namun pada tahun 2014 menjadi 22,43\%. Penurunan ini mencerminkan bank semakin ke arah tidak likuid. Penurunan cadangan likuiditas dapat berakibat pada risiko likuiditas bank. Hal ini diterjadi karena adanya ketidaksesuaian likuiditas diantara kedua sisi neraca, mengingat peran utama perbankan adalah untuk menyediakan likuiditas melalui intermediasi diantara depositor dengan debtor. Dengan kata lain, bank bertugas untuk merubah deposito jangka pendek yang lancar milik depositor menjadi kredit jangka panjang yang lebih tidak lancar untuk dipinjamkan kepada debtor. Ketidaksesuaian waktu jatuh tempo ini menciptakan ketidak-stabilan pada peran bank dalam menyediakan likuiditas bagi deposan, dan menimbulkan tingginya risiko likuiditas perbankan.

Bank yang dikelola dengan baik memiliki mekanisme untuk mengidentifikasi, mengukur, memonitor dan mengurangi risiko likuiditasnya. Kerapuhan bank tidak dapat dihindari, maka bank secara terus-menerus selalu berusaha menjaga keseimbangan dari berbagai faktor internal maupun eksternal sesuai dengan toleransi masing-masing Bank terhadap risiko. Namun, terlepas dari tingkat keagresifan bank dalam menghasilkan profit dan menanggung risiko, penting bagi bank untuk mengetahui variabel apa yang berpengaruh untuk mencapai target likuiditas yang mereka tetapkan.

Menurut model seperti yang diungkapkan oleh Kiyotaki dan Moore (2008), kebutuhan likuiditas tergantung pada ketidak-sempurnaan pasar, yaitu asimetri informasi. Maka bank yang secara finansial terdesak akan memiliki kecenderungan untuk menyimpan lebih banyak cadangan likuiditas. Berdasarkan model tersebut, karakteristik bank, yang berpengaruh pada kemampuan mereka untuk meningkatkan dana non-deposit, akan memengaruhi kebutuhan cadangan likuiditas bank.

Studi empirisnya Mehmed (2014) menemukan bahwa kapitalisasi bank, besarnya kredit macet, profitabilitas, cadangan kerugian penurunan nilai, ukuran bank, rasio cadangan kas, dan rasio pinjaman atas deposito, berpengaruh terhadap risiko likuiditas. Hasil penelitian Mehmed mendukung beberapa penelitian terdahulu, seperti Deléchat (2012) yang meneliti determinan risiko likuiditas perbankan di Amerika Tengah, Vodová (2013) yang meneliti hal serupa pada bank-bank komersil di Ceko dan Slovakia, serta Sohaimi (2013) di Malaysia. Mengacu pada penelitian-penelitian sebelumnya, penelitian ini akan menggunakan ketujuh karakteristik di atas untuk melihat dampaknya terhadap risiko likuiditas bank swasta nasional devisa di Indonesia. Pengukuran likuiditas pada penelitian ini sesuai dengan penelitian-penelitian terdahulu (Deléchat, et. al., 2012, Mehmed, G., 2014) yang menggunakan dua alternatif rasio likuiditas. Rasio yang pertama adalah proporsi aset lancar bank atas seluruh aset yang dimilikinya, dimana rasio ini menggambarkan risiko likuiditas pada sisi aset neraca. Rasio yang kedua adalah proporsi aset lancar terhadap total deposito nasabah dan antar-bank dalam jangka pendek, dimana rasio ini dapat menjelaskan kesenjangan likuiditas yang terjadi diantara kedua sisi neraca bank.

Penelitian ini menguji pengaruh karakteristik bank terhadap risiko likuiditas bank swasta nasional devisa di Indonesia. Karakteristik perbankan yang dimaksud di dalam penelitian ini 
adalah rasio kapitalisasi, risiko kredit, ukuran bank, profitabilitas, cadangan kerugian, cadangan kas, dan profil pendanaan jangka pendek. Dengan demikia, Lebih spesifik, penelitian ini menguji apakah kapitalisasi bank, besarnya risiko kredit, ukuran bank, profitabilitas, cadangan kerugian penurunan nilai, rasio cadangan kas dan profil pendanaan jangka pendek berpengaruh terhadap risiko likuiditas.

\section{KAJIAN PUSTAKA DAN HIPOTESIS}

Likuiditas dalam pengertian sederhana adalah kemampuan perusahaan untuk menutupi kewajibannya terhadap kreditor yang memerlukan dana pada saat yang tidak tepat, dinyatakan dalam jumlah terukur. Jika likuiditas tidak dikelola dengan cara yang benar, perusahaan dapat menghadapi situasi tidak likuid (ilikuiditas) dan secara teknis akan menjadi bangkrut atau menghadapi kerugian. Tidak ada manajer yang ingin memimpin perusahaan dalam situasi ini. Itulah alasan utama mengapa perusahaan harus siap beradaptasi dengan kondisi ekonomi yang tidak menguntungkan dan kemungkinan perubahan agar tetap berada di pasar dan tidak merusak citra dan hubungan perusahaan dengan pemangku kepentingan (Hawawini and Vialler, 2007).

Likuiditas berarti kemampuan perusahaan untuk menutupi kewajibannya tanpa mengalami kerugian. Dari pandangan tersebut terdapat pandangan yang jelas tentang pentingnya likuiditas: jika perusahaan atau institusi tidak cukup likuid, perusahaan tersebut akan menderita kerugian secara finansial. Banyak contoh melalui sejarah yang membuktikan pentingnya pengelolaan likuiditas yang tepat. Bank harus diperlengkapi untuk menghadapi perubahan kebijakan moneter yang membentuk tren likuiditas keseluruhan dan persyaratan transaksional bank dan pelunasan pinjaman jangka pendek (Akhtar, 2007).

Semenatara itu, risiko likuiditas adalah ketidakmampuan Bank untuk memenuhi kewajibannya (Jenkinson, 2008) karena deposan menarik dana mereka pada saat yang tidak tepat, yang menyebabkan penjualan aset dengan harga murah (Diamond dan Rajan 2001), serta berdampak negatif pada profitabilitas bank (Chaplin, Emblow, dan Michael, 2000). Risiko likuiditas adalah potensi kerugian bagi institusi yang timbul dari ketidakmampuannya untuk memenuhi kewajibannya atau untuk mendanai kenaikan aset karena jatuh tempo tanpa menimbulkan biaya atau kerugian yang tidak dapat diterima. Dalam hal ini, penting bagi bank untuk mengukur risiko likuiditas, karena pengukuran yang akurat dapat membantu menghindari risiko dengan memusatkan pada rasio seperti aset lancar terhadap total aset dan kewajiban likuid terhadap total kewajiban (Goddard, Molyneux, and Wilson, 2009).

Penting bagi bank untuk memiliki cadangan likuiditas yang mencukupi untuk menjaga mereka dari risiko likuiditas. Farag, Harland, dan Nixon, (2013) menjabarkan risiko likuiditas yang dihadapi bank menjadi dua jenis, pertama; risiko likuiditas pendanaan, dan kedua; risiko likuiditas pasar. Risiko likuiditas pendanaan terjadi saat bank tidak memiliki cukup kas atau aset likuid lainnya untuk membayar kewajiban kepada nasabah atau pihak lainnya pada saat jatuh tempo. Kondisi ini setara dengan kegagalan bank atau default, atau dapat juga disebut sebagai kegagalan arus kas. Risiko likuiditas pasar terjadi saat sebuah aset tidak dapat dijual kepada pasar dengan cepat, atau pada saat aset hanya dapat dijual pada harga diskon yang tidak sesuai pada nilai seharusnya. Kondisi pasar tersebut dapat berujung pada kerugian bank dan menurunkan nilai modalnya.

Pada dasarnya, likuiditas terhubung pada kedua sisi neraca perbankan. Likuiditas perbankan berhubungan dengan aset yang dimilikinya dan juga berhubungan dengan berbagai sumber dana yang pada saat yang ditentukan harus dibayar kembali. Maka untuk mengurangi risiko likuiditas yang dihadapinya, bank dapat melakukan dua cara. Pertama, bank dapat 
mencari sumber dana yang stabil dan memiliki sedikit kecenderungan untuk menarik dananya pada saat kondisi pasar buruk. Kedua, bank dapat memegang lebih banyak cadangan atau aset yang likuid untuk dapat digunakan saat utang mereka jatuh tempo. Cadangan ini menjadi sangat penting saat bank tidak dapat memperbarui sumber dananya atau saat aset lain yang dimilikinya sulit untuk dilikuidasi.

Cadangan atas aset likuid bersumber pada kas dan aset lainnya yang dapat dengan mudah dicairkan dengan sedikit biaya. Cadangan aset likuid membantu mengurangi risiko likuiditas dalam dua cara. Pertama, ia menjadi sumber likuiditas untuk menjamin pembayaran liabilitas pada saat jatuh tempo di masa-masa krisis. Kedua, keberadaan cadangan aset likuid memberikan jaminan dan ketenangan kepada deposan bahwa bank tersebut akan dapat selalu melunasi liabilitasnya. Cadangan likuiditas dalam bentuk aset harus tetap mudah dicairkan pada situasi ekonomi yang buruk. Basel Committee on Banking Supervision (BCBS) memberi batasan karakteristik aset yang likuid. Hal ini diterapkan oleh Bank Indonesia dan lebih sering disebut sebagai kas dan setara kas. Kas dan setara kas terdiri dari kas, giro pada Bank Indonesia, giro pada bank lain, penempatan pada bank lain dan Bank Indonesia, Sertifikat Bank Indonesia, efekefek dan obligasi pemerintah. Bagi penempatan pada bank lain dan Bank Indonesia, Sertifikat Bank Indonesia, serta efek-efek dan obligasi pemerintah, hanya yang berjangka waktu jatuh tempo tiga bulan atau kurang saja yang dapat diklasifikasikan ke dalam kas dan setara kas.

Determinan dari cadangan likuiditas perbankan sesuai teori keuangan, dapat diklasifikasikan ke dalam empat kategori. Pertama, opportunity cost dan risiko atas pendanaan. Pada awal pengembangan teori likuiditas, cadangan likuiditas dihitung sesuai dengan opportunity cost dari aset likuid yang disimpannya. Ia juga harus menggambarkan volatilitas pendanaan dan mencakup biaya yang perlu dikeluarkan jika bank harus mencari sumber dana baru. Kedua, karakteristik bank, dimana teori menjelaskan bahwa kebutuhan cadangan likuiditas tergantung pada ketidak-sempurnaan pasar karena pasar yang tidak sempurna mengandung asimetri informasi sehingga bank tidak dapat mencapai likuiditas yang tak terbatas dalam waktu sekejap. Berangkat dari dasar pemikiran tersebut, disimpulkan bahwa bank yang secara finansial terbatas akan memiliki kecenderungan untuk menyimpan lebih banyak cadangan likuiditas. Sehingga karakteristik bank yang berpengaruh pada kemampuan mereka untuk meningkatkan dana non-deposit, dinilai berpengaruh terhadap kebutuhan cadangan likuiditas bank. Ketiga, makroekonomi fundamental, dimana jika pasar modal tidak sempurna maka kebutuhan cadangan likuiditas perbankan seharusnya berkorelasi negatif dengan siklus ekonomi. Teori ini didasari pada pemikiran bahwa bank akan cenderung mengumpulkan cadangan likuiditas pada saat resesi dan akan menguranginya pada saat kondisi ekonomi yang baik untuk meningkatkan peluang pemberian kredit. Keempat, risiko moral dan safety nets, dimana semakin kuat dan besar safety nets perbankan, dalam hal ini keberadaan bank sentral sebagai Lender of Last Resort (LOLR), semakin kecil kecenderungan bank dalam menyimpan cadangan likuiditas.

Pada penelitian terdahulu, Mehmed (2014) melakukan studi empiris mengenai determinan atas likuiditas 17 dari 28 bank komersil di Bosnia dan Herzegovina dalam periode 2002 hingga 2012. Dengan menggunakan dua alternatif rasio likuiditas sebagai variabel dependen, ia menguji pengaruh sembilan variabel independen, yaitu; kapitalisasi atau kecukupan modal bank, risiko kredit yang ditanggung oleh bank, profitabilitas bank, cadangan kerugian yang diterapkan oleh bank, besarnya bank dilihat dari asetnya, cadangan kas milik bank, profil pendanaan jangka pendek bank, persebaran suku bunga, dan pertumbuhan gross domestic products (GDP). Hasil regresi menunjukkan bahwa kapitalisasi, risiko kredit, profitabilitas, 
cadangan kerugian, ukuran bank, cadangan kas dan profil pendanaan jangka pendek berpengaruh terhadap kedua rasio yang menggambarkan cadangan likuiditas. Pada kesembilan variabel, dua variabel yang tidak berpengaruh signifikan, yaitu; persebaran suku bunga dan GDP, terklasifikasi sebagai determinan makroekonomi fundamental.

\section{Pengembangan Hipotesis Kapitalisasi dan Risiko Likuiditas}

Kapitaliasi mempengaruhi risiko likuiditas. Kapitalisasi bank mewakili kekayaan bersih bank atau nilai bagi investor. Untuk memiliki modal standar, maka bank harus memiliki modal sepadan dengan besarnya risiko kredit yang merupakan modal yang mempengaruhi ukuran portofolio pinjaman. Namun menurut Karim dan Verhoeven (2005) modal dalam sistem perbankan meningkatkan kepercayaan deposan dan secara tidak langsung mengurangi risiko likuiditas. Hal ini juga menunjukkan bahwa kenaikan modal bank akan mengurangi masalah pada portofolio kredit dan dengan demikian akan meningkatkan rasio loan to deposit. Indriani (2008) juga menyatakan bahwa deposan harus mengasuransikan pinjamannya ketika mayoritas adalah deposan yang dapat mempengaruhi perubahan tingkat modal. Ini adalah efek dari modal portofolio pinjaman yang didominasi olehjdeposan. Pernyataan ini menunjukkan bahwa modal bank memiliki hubungan positif dengan risiko likuiditas. Hasil penelitian sebelumnya (Deléchat, et al, 2012; Mehmed, 2014; Zolkifli, Hamidand, and Janor, 2015) menunjukkan bahwa kapitalisasi bank berpengaruh positif terhadap risiko kredit. Berdasarkan penjelasan teori dan hasil penelitian sebelum, dapat dihipotesiskan sebagai berikut:

$\mathrm{H}_{1}$ : kapitalisasi berpengaruh positif terhadap risiko likuiditas.

\section{Risiko Kredit dan Risiko Likuiditas}

Roman and Sargu, (2015) menyatakan bahwa risiko kredit berdampak pada risiko likuiditas melalui jalur permintaan deposan. Mereka menjelaskan bahwa jika bank memberikan pinjaman kepada banyak proyek ekonomi yang tertekan, nilai aset bank akan memburuk. Konsekuensinya adalah deposan akan mengklaim kembali uang mereka yang menyebabkan masalah likuiditas. Mengenai dampak non-performing loan (NPL) terhadap likuiditas bank, diharapkan terjadi penurunan kualitas portofolio kredit, karena adanya peningkatan rasio kredit bermasalah terhadap total kredit, akan berdampak negatif terhadap keseluruhan kredit (Belaid, Bellouma, Omri, 2016.)

Secara teoretis, risiko likuiditas dan risiko kredit berkorelasi positif. Hubungan positif antara dua risiko perbankan utama ini dapat dijelaskan oleh fakta bahwa pada saat default pinjaman meningkat, likuiditas bank menurun karena turunnya arus kas masuk dan depresiasi yang diakibatkannya Imbierowicz dan Rauch, (2014) menyelidiki hubungan antara risiko likuiditas dan risiko kredit dengan menggunakan sampel bank AS selama periode 1998-2010. Hasil penelitian menunjukkan bahwa risiko kredit tidak berpengaruh secara signifikan terhadap risiko likuiditas. Ini terjadi karena aset likuid berubah menjadi tidak likuid. Ghosh, (2015) berpendapat bahwa kenaikan pangsa NPL dalam portofolio pinjaman bank menyebabkan risiko lebih besar yang mempengaruhi likuiditas dan profitabilitas bank.

Variabel Non Performance Loan menggambarkan besarnya risiko kredit yang ditanggung bank dari keseluruhan kredit yang mereka berikan. Semakin tinggi nilai NPLnya, semakin besar risiko likuiditas yang ditanggung oleh bank. Hasil penelitian sebelumnya menyatakan bahwa risiko kredit akan berpengaruh negatif pada risiko likuiditas bank (Vodová, 2013; Belaid, Bellouma, dan Omri. 2016; ). Berbeda dengan hasil penelitian Vodová (2013), Mehmed (2014) mendapati risiko kredit berelasi negatif terhadap risiko likuiditas bank komersil 
di Bosnia dan Herzegovina. Hasil mereka membuktikan bahwa kualitas aset yang buruk akan menurunkan profitabilitas dan likuiditas. Penelitian ini juga mendukung hasil penelitian serupa yang dilakukan oleh Sohaimi (2013) di Malaysia. Berdasarkan penjelasan teori dan hasil penelitian sebelum, dapat dihipotesiskan sebagai berikut:

$\mathrm{H}_{2}$ : risiko kredit berpengaruh terhadap risiko likuiditas.

\section{Ukuran Bank dan Risiko Likuiditas}

Variabel ukuran bank ini menggambarkan besarnya bank berdasarkan aset yang dimilikinya. Berbagai penelitian sebelumnya telah dilakukan untuk menguji pengaruh ukuran bank terhadap risiko likuiditas. Sawada (2010) telah melakukan penelitian sehubungan dengan likuiditas dan pengurangan portofolio bank dalam sistem keuangan tanpa asuransi deposito di Jepang. Penelitian tersebut menemukan bahwa ada hubungan positif antara ukuran bank dan likuiditas. Hal ini menunjukkan bahwa bank yang berukuran besar biasanya memiliki lebih banyak pinjaman dan memiliki kesenjangan pembiayaan yang lebih besar dan ini adalah salah satu masalah likuiditas perbankan. Mereka menemukan ukuran bank dan likuiditas memiliki hubungan positif. Zolkifli, Hamidand, and Janor, (2015), juga menemukan ukuran bank dan likuiditas memiliki hubungan positif.

Bank yang lebih kecil cenderung lebih terbatas, sehingga akan lebih terjamin jika ia memegang lebih banyak likuiditas. Deléchat (2012) menyatakan bahwa bank yang lebih kecil cenderung memiliki cadangan likuiditas yang lebih tinggi. Hal ini dapat disebabkan oleh keterbatasan finansial bank kecil dalam memperoleh dana sehingga bank kecil cenderung memegang likuiditas yang lebih tinggi. Sementara itu, Vodová (2013) juga mendapati hasil yang serupa, dan sejalan dengan prinsip "too big to fail", dimana bank besar yang dianggap terlalu besar untuk dapat mengalami kegagalan akan lebih dipercaya oleh pemberi pinjaman, sehingga bank besar cenderung memiliki motivasi yang terbatas untuk memegang cadangan likuiditas yang tinggi. Berdasarkan penjelasan teori dan hasil penelitian sebelum, dapat dihipotesiskan sebagai berikut:

$\mathrm{H}_{3}$ : ukuran bank berpengaruh terhadap risiko likuiditas.

\section{Profitabilitas dan Risiko Likuiditas}

Roman dan Sargu, (2015) menyatakan bahwa bank dengan tingkat profitabilitas tinggi cenderung memiliki likuiditas lebih banyak daripada bank lain yang mencatat tingkat pengembalian yang lebih rendah. Hal ini karena imbal hasil tambahan tidak selalu didistribusikan di tahun pertama perolehannya. Hal ini menyebabkan kenaikan laba ditahan bank yang berdampak positif pada tingkat likuiditasnya. Namun, imbal hasil atau kerugian yang lebih rendah berdampak negatif pada laba ditahan bank, sehingga menyebabkan penurunan likuiditas secara keseluruhan.

Profitabilitas bank mungkin juga merupakan proksi untuk kualitas pengelolaan bank (Louzis, Vouldis, dan Metaxas, 2012). Dari perspektif ini, kinerja yang buruk akan menandakan semakin rendahnya kualitas kemampuan manajer bank dalam hal kemampuan mereka untuk mengumpulkan dana dalam bentuk deposito dengan biaya terjangkau sehingga menghambat likuiditas bank.

Sementara itu, teori dasar atas hubungan negatif profitabilitas dengan likuiditas didukung penelitian yang dilakukan oleh Delechat, et al. (2012), yang menyatakan, semakin tinggi profit yang mampu dihasilkan, semakin mudah bank meningkatkan modalnya, sehingga memiliki kecenderung untuk memegang lebih sedikit cadangan likuiditas. Mehmed (2014) 
membuktikan bahwa profitabilitas berpengaruh negatif terhadap likuiditas. Hasil penelitian ini mendukung penelitian sebelumnya (Dinger 2009; Aspachs, et al. 2005). Dengan mendasarkan pada penjelasan teoretis di atas, dapat dirumuskan hipotesis sebagai berikut:

$\mathrm{H}_{4}$ : profitabilitas berpengaruh negatif terhadap risiko likuiditas.

\section{Cadangan Kerugian dan Risiko Likuiditas}

Variabel cadangan kerugian menunjukkan penilaian bank terhadap risiko kredit yang dapat ditanggungnya. Deléchat (2012) menyatakan bahwa bank yang mengantisipasi kerugian yang tinggi, akan cenderung memiliki tingkat likuiditas yang tinggi pula. Namun penelitiannya menunjukkan hubungan negatif antara cadangan kerugian yang dimiliki bank dengan likuiditas perbankan di Amerika Tengah. Hasil ini mengindikasikan bank dengan simpanan yang tinggi atas potensi merugi atau memiliki portofolio kredit yang lebih berisiko cenderung memiliki cadangan likuiditas yang rendah. Dengan mendasarkan pada penjelasan teoretis di atas, dapat dirumuskan hipotesis sebagai berikut:

$\mathrm{H}_{5}$ : cadangan kerugian pinjaman berpengaruh positif terhadap risiko likuiditas.

\section{Cadangan Kas dan Risiko Likuiditas}

Variabel cadangan kas menggambarkan besarnya cadangan kas, aset terlikuid pada neraca, yang dimiliki oleh bank terhadap liabilitas jangka pendeknya. Variabel ini menggambarkan besarnya proporsi dana nasabah yang disimpan oleh bank untuk mendanai transaksi-transaksi tak terduga. Bank mungkin harus meningkatkan cadangan kasnya untuk mengurangi risiko likuiditas, namun mungkin harganya mahal (Holmstrom dan Tirole, 2000). Diamond dan Rajan (2001) menyatakan bahwa bank dapat menolak pemberian pinjaman, bahkan kepada calon pengusaha yang bisa mendatangkan keuntungan bagi bank, jika Bank merasa pentingnya kebutuhan likuiditas bank yang cukup tinggi. Penghindaran risiko likuiditas adalah alasannya, mengapa setiap bank berusaha untuk mencukupi kebutuhan dana untuk memenuhi permintaan tak terduga dari deposan. Mehmed (2014) menemukan bahwa cadangan kas milik bank berelasi positif terhadap risiko likuiditas. Semakin tinggi kas, semakin likuid bank tersebut. Berdasarkan penjelasan dan hasil penelitian sebelumnya dapat mengarah kepada hipotesis sebegai berikut:

$\mathrm{H}_{6}$ : cadangan kas berpengaruh positif terhadap risiko likuiditas.

\section{Pinjaman atas Deposit dan Risiko Likuiditas}

Loan to deposit ratio (LD) juga merupakan salah satu faktor penentu risiko likuiditas. Jika rasio LD rendah, ini mengindikasikan bahwa bank memiliki lebih sedikit sumber dana dan setoran untuk pendanaan atau pinjaman juga menunjukkan risiko likuiditas yang lebih rendah. Menurut Golin (2001) jika LD meningkat, paparan deposit yang lebih besar tidak dapat dipenuhi. Hasil ini juga didukung oleh Indriani (2008) yang menemukan bahwa LD rendah akan menjamin bank dapat memenuhi penarikan yang besar dari deposan serta pinjaman tak terduga. Dengan demikian, LD memiliki hubungan positif dengan risiko likuiditas. Mehmed (2014) menemukan loan to deposit (LTD) berdampak negatif pada risiko likuiditas pada model 1 , namun berdampak positif pada risiko likuiditas pada model 2 . Berdasarkan penjelasan teori dan hasil penelitian sebelumnya, dapat dirumuskan hipotesis sebagai berikut:

$\mathrm{H}_{7}$ : Pinjaman dari deposan berpengaruh terhadap risiko likuiditas. 


\section{METODE PENELITIAN}

\section{Data}

Data yang digunakan pada penelitian ini diambil dari laporan keuangan tahunan Bank Swasta Nasional Devisa (Konvensional). Teknik penentuan sampel adalah purposive sampling, yaitu sampel didasarkan pada kriteria tertentu. Bank yang digunakan sebagai objek penelitian adalah bank yang sebagian besar sahamnya dimiliki oleh swasta nasional serta akte pendiriannya pun didirikan oleh swasta, memiliki izin melayani valuta asing serta berprinsip konvensional, atau dapat disebut sebagai Bank Swasta Nasional Devisa (Konvensional). Berdasarkan data ada tiga puluh dua bank swasta nasional devisa, namun hanya 21 perusahaan yang menyediakan data dengan lengkap dan tidak mengalami merger maupun akuisisi pada periode tahun 2010 hingga 2015.

Risiko likuiditas mendasarkan pada dua proksi. Pertama besarnya aset lancar berbanding dengan total aset yang dimiliki bank. Walaupun menggambarkan proporsi antara aset yang lancar dengan yang tidak lancar, pengukuran ini tidak dapat menangkap kesenjangan likuiditas yang terjadi di dalam neraca keuangan bank. Kedua, rasio likuiditas, aset lancar terhadap total deposito dan deposito bank lain, digunakan.

Variabel independen yang akan diuji adalah ketujuh variabel. Pengukuran ketujuh variabel tersebut dirangkum seperti pada tabel 1 berikut:

\section{Tabel 1}

Definisi Operasional Variabel Independen dan Dependen

\begin{tabular}{|c|c|c|}
\hline No & Variabel & Pengukuran \\
\hline $\mathbf{A}$ & \multicolumn{2}{|l|}{ Variabel Independen } \\
\hline 1 & Kapitalisasi (CAP) & Total Ekuitas $\div$ Total Aset \\
\hline 2 & Risiko Kredit (NPL) & $\begin{array}{l}\text { Pinjaman yang Tidak Menghasilka } \\
\quad \quad \div \text { Pinjaman yang Diberikan } \\
\text { Keterangan: } \\
\text { Pinjaman yang tidak menghasilkan adalah pinjaman dengan } \\
\text { status "kurang lancar/substandard", "diragukan/doubtful" dan } \\
\text { "macet/loss" }\end{array}$ \\
\hline 3 & Ukuran Bank (TOA) & Logaritma Natural dari Total Aset \\
\hline 4 & Profitabilitas (ROE) & Laba Bersih $\div$ Total Ekuitas \\
\hline 5 & $\begin{array}{l}\text { Cadangan Kerugian } \\
\text { (LLR) }\end{array}$ & $\begin{array}{r}\text { Cadangan Kerugian Pinjaman Penurunan Nilai } \\
\div \text { Pinjaman yang Diberikan (kotor) }\end{array}$ \\
\hline 6 & $\begin{array}{l}\text { Cadangan } \quad \text { Kas } \\
(\mathrm{CRR})\end{array}$ & $\begin{array}{l}\text { cash } \div \text { Deposito } \\
\text { Keterangan: } \\
\text { Deposito yang dimaksud adalah deposito nasabah. }\end{array}$ \\
\hline 7 & $\begin{array}{l}\text { Pinjaman (loan) } \\
\text { (LTDP) }\end{array}$ & Pinjaman yang Diberikan $\div$ Deposito \\
\hline $\mathbf{B}$ & \multicolumn{2}{|l|}{ Variabel Dependen } \\
\hline & Risiko Likuiditas & Aset Lancar $\div$ Total Aset \\
\hline & & Aset Lancar $\div$ Total Deposito \\
\hline
\end{tabular}

\section{Metode Empiris}

Setelah memutuskan metoda regresi yang akan digunakan pada kedua model regresi, pengujian model empiris akan dilakukan dengan menggunakan regresi linier berganda untuk 
menguji signifikansi stastistik, seperti; $R$-squared, Uji F dan Uji t. Model yang digunakan dapat dirumuskan sebagai berikut:

Model $: R L=\beta 0+\beta 1 C A P T$ it $+\beta 2 N P L i t+\beta 3$ SIZE it $+\beta 4$ ROE it + $\beta 5 C D R P$ it $+\beta 6 C D C H$ it $+\beta 7$ LTDP it $+e$ it

Dimana:

RL terdiri RL1 = Risiko likuiditas (dengan proksi: aset lancar / total aset); RL, $2=$ Risiko likuiditas (dengan proksi: aset lancar / total deposito); CAPT = Kapitalisasi; NPL = Risiko Kredit; SIZE = Ukuran Bank; ROE = Profitabilitas; CDRP = Cadangan Kerugian Pinjaman; $\mathrm{CDCH}=$ Cadangan Kas; LTDP = Pinjaman

\section{HASIL DAN PEMBAHASAN \\ Statistik Deskriptif}

Data penyusun seluruh variabel yang digunakan pada penelitian kali ini adalah nilainilai rasio yang dihitung menggunakan data laporan keuangan tahunan dua puluh satu bank sampel selama lima tahun. Dari keseluruhan data yang didapat, terbentuk data deskriptif sebagai berikut.

Tabel 2

Data deskriptif

\begin{tabular}{llccccccc}
\hline \multicolumn{1}{c}{ Variabel } & Lambang & $\mathbf{N}$ & Range & Min & Max & Mean & $\begin{array}{c}\text { Std. } \\
\text { Dev }\end{array}$ & Varians \\
\hline Kapitalisasi & CAPT & 132 & .143 & .060 & .203 & .115 & .029 & .001 \\
Risiko Kredit & NPL & 132 & .074 & .001 & .075 & .018 & .013 & .000 \\
Ukuran Bank & SIZE & 132 & 2.696 & 12.022 & 14.811 & 13.328 & .745 & .555 \\
Profitabilitas & ROE & 132 & .369 & .012 & .381 & .109 & .056 & .003 \\
Cadangan & CDRP & 132 & .038 & .001 & .039 & .015 & .009 & .000 \\
Kerugian & & & & & & & \\
Cadangan Kas & CDCH & 132 & .042 & .002 & .044 & .018 & .009 & .000 \\
Pinjaman & LTDP & 132 & .672 & .438 & 1.110 & .800 & .114 & .013 \\
Risiko Likuiditas & RISKL1 & 132 & .357 & .082 & .439 & .193 & .067 & .004 \\
& RISKL2 & 132 & .463 & .076 & .539 & .233 & .080 & .006 \\
\hline
\end{tabular}

Sebagai variabel dependen pertama, risiko likuiditas pada Model 1 menggambarkan kebijakan bank dalam melakukan manajemen risiko likuiditas. Pada model 1, rata-rata likuiditasnya ada pada tingkat 19,7\% dari keseluruhan aset yang dimilikinya dan pada Model 2 rata-rata likuiditas, 23,7\%. Kapitalisasi menggambarkan kualitas modal di bank di Indonesia. Dengan melihat proporsi aset yang didanai dana milik perusahaan, rata-rata bank di Indonesia memiliki modal pribadi sebesar 11,5\%. Modal yang mereka miliki dapat menjamin pengembalian utang jika terjadi penagihan hutang serentak, namun kecenderungannya ekuitas bank hanya akan betul-betul dicairkan jika bank sudah mengalami kerugian dan kehabisan cadangan aset yang lebih likuid.

Risiko Kredit dengan nilai rata-rata sebesar 0,018 artinya bank di Indonesia mampu mengatur risiko kreditnya sedemikian rupa hingga kredit bermasalah hanya berkisar 1,8\% dari keseluruhan kredit yang disalurkan kepada masyarakat. Profitabilitas bank pada penelitian ini dilihat dari presentase laba bersihnya terhadap ekuitas yang dimiliki. Nilai rata-rata sebesar 
10,9\% menggambarkan besarnya persentase laba yang dapat dihasilkan oleh bank di Indonesia. Rasio Cadangan Kerugian dengan rata-rata 1,5\%.

Bank menyimpan sejumlah kas sebagai cadangan likuiditas operasional dimana nasabah selalu menarik dananya sewaktu-waktu. Rata-rata cadangan kas yang dimiliki bank adalah sebesar $1,8 \%$ dari besarnya deposito yang diterima dari nasabah. Terdapat bank yang menyediakan cadangan kas sebesar 1,8\% dari simpanan nasabah untuk cadangan likuiditas, dan terdapat pula bank yang memilih untuk memutar hampir seluruh kasnya ke dalam bentuk aset lain yang lebih menghasilkan, menyisakan hanya $0,2 \%$ kas pada neracanya. Selanjutnya, pinjaman bank menunjukkan proporsi kredit bank yang didanai oleh dana nasabah. Terlihat proporsi rata-rata yang sangat tinggi sebesar $80 \%$.

Hasil dari uji Kolmogorov-Smirnov menunjukkan nilai Asymp.Sig. (2-tailed) >0,05, pada model 1 (0.793) dan pada model 2 (0.668) maka dapat disimpulkan bahwa residual berdistribusi secara normal. Selanjutnya, hasil uji multikolinearitas baik pada model 1 maupun pada model 2, menunjukkan untuk semua variabel penjelas hasil tolerance kurang dari dari $<$ 0,10 dan VIF d iatas $>10$, maka hasil ini mengindikasikan tidak terjadinya multikolinearitas. Hasil uji heteroskedastisitas pada model 1 dan 2 menunjukkan setiap variabel independen memiliki nilai signifikansi $>0,05$ yang artinya tidak mengalami heteroskedastisitas. Hasil uji Durbin-Waston pada model 1 menunjukkan bahwa nilai Durbin-Waston sebesar 1,497 lebih kecil dari DL yakni 1,637. Hasil uji Durbin-Waston pada model 2 menunjukkan bahwa nilai Durbin-Waston sebesar 1,254 lebih kecil dari DL yakni 1,637. Hasil uji ini menunjukkan bahwa tidak terjadi aukorelasi positif.

Uji F, secara keseluruhan, signifikansi pengaruh karakteristik bank dapat dilihat dari nilai Fstatistik. Nilai F-statistik Model 1 adalah sebesar 14.210 dan p-value $(0,000)$. Pada Model 2, nilai F-statistiknya mencapai 9.721 dan p-value $(0,000)$. Hasil ini menunjukkan bahwa baik model 1 dan 2 model, ketujuh karakteristik bank secara serentak mempunyai pengaruh terhadap perubahan risiko Likuiditas.

Koefisien Determinasi $\left(\mathrm{R}^{2}\right)$, untuk model 1, nilai $R$-squared yang muncul adalah sebesar .427 artinya Model 1 mampu dijelaskan secara serentak oleh seluruh variabel independen sebesar $42,7 \%$, sedangkan $58,3 \%$ sisanya dijelaskan oleh faktor-faktor lain yang tidak masuk dalam model. Pada Model 2, nilai $R$-squared menunjukkan angka 0.330 artinya Model 2 mampu dijelaskan secara serentak oleh seluruh variabel independen sebesar $33 \%$, sedangkan $77 \%$ sisanya dijelaskan oleh faktor-faktor lain yang tidak masuk dalam model.

\section{Hasil Uji Hipotesis}

Penelitian ini menguji pengaruh karakteristik bank terhadap risiko likuiditas. Jika nilai probabilitas lebih kecil dari standar 0,05 ( $\mathrm{p}$-value $<0,05$ ) maka sebuah karakteristik bank dinilai berpengaruh. Kemudian untuk menguji arah dari pengaruh tersebut serta melihat besar koefisien beta variabel penjelasa terhadap risiko likuiditas. Jika nilai koefisiennya bernilai negatif, maka arah pengaruh variabel penjelas terhadap risiko likuiditas adalah berlawanan. Sebaliknya, jika nilai koefisiennya bernilai positif, maka arah pengaruh variabel penjelas terhadap risiko likuiditas adalah searah. Hasil analisis menunjukkan pengaruh masing-masing variabel penjelas terhadap risiko kredit, sebagai mana disajikan pada tabel 2. 
Tabel 3.

Hasil Uji Hipotesis

\begin{tabular}{|c|c|c|c|c|c|}
\hline \multirow{2}{*}{ Variabel } & \multirow{2}{*}{$\begin{array}{c}\text { Lambang } \\
\text { Variabel }\end{array}$} & \multicolumn{2}{|c|}{ Model 1} & \multicolumn{2}{|c|}{ Model 2} \\
\hline & & Koefisien & Sig & Koefisien & Sig \\
\hline Kapitalisasi & CAPT & 0.581 & 0.001 & 0.930 & 0.000 \\
\hline Risiko Kredit & NPL & 0.460 & 0.212 & 0.761 & 0.113 \\
\hline Ukuran Bank & SIZE & -0.003 & 0.703 & 0.003 & 0.800 \\
\hline Profitabilitas & ROE & -0.044 & 0.642 & -0.128 & 0.297 \\
\hline Cadangan Kerugian & CDRG & -0.589 & 0.370 & -0.156 & 0.855 \\
\hline Cadangan Kas & $\mathrm{CDCH}$ & -1.271 & 0.024 & -1.838 & 0.012 \\
\hline Pinjaman atas deposan & LTDP & -0.388 & 0.000 & -0.403 & 0.000 \\
\hline Nilai F & & 14.210 & 0.000 & 9.721 & 0.000 \\
\hline Nilai $R^{2}$ adjusted & & .427 & & 0.330 & \\
\hline
\end{tabular}

Hasil pengujian pada model 1, menunjukkan bahwa nilai koefisien kapitalisasi (CAPT) sebesar 0.581 dan $p$-value $=0.001<\alpha=0,05$. Hasil ini menjelaskan bahwa variabel kapitalisasi berpengaruh positif terhadap risiko likuiditas. Nilai koefisien positif mengindikasikan jika kapitalisasi mengalami kenaikan, maka risiko likuiditas akan mengalami kenaikan. Dengan kata lain kapitalisasi berpengaruh positif terhadap risiko likuiditas. Hasil ini mendukung hipotesis bahwa kapitalisasi berpengaruh positif terhadap risiko likuiditas. Sementara itu, pada Model 2, kapitalisasi menunjukkan nilai koefisien sebesar 0.930 dan $p$-value $=0,047<\alpha=0,05$. Nilai koefisien Kapitalisasi menunjukkan arah positif dan signifikan. Hasil ini juga mendukung hipotesis ke satu yang menyatakan bahwa kapitalisasi berpengaruh positif terhadap risiko likuiditas.

Selanjutnya, hasil model 1, menunjukkan bahwa nilai koefisien risiko kredit (NPL) sebesar 0.460 dan $p$-value $=0.212>\alpha=0,05$. Hasil ini menjelaskan bahwa variabel risiko kredit tidak berpengaruh terhadap risiko likuiditas. Hasil ini tidak mendukung hipotesis kedua, bahwa risiko kredit (NPL) tidak berpengaruh terhadap risiko likuiditas. Demikian juga, pada Model 2, risiko kredit (NPL) menunjukkan nilai koefisien sebesar .761 dan $p$-value $=0.113>$ $\alpha=0,05$. Nilai koefisien risiko kredit (NPL) positif dan tidak signifikan. Hasil ini juga tidak mendukung hipotesis ke kedua yang menyatakan bahwa risiko kredit (NPL) berpengaruh terhadap risiko likuiditas.

Hasil model 1, nilai koefisien Ukuran Bank sebesar -0.003 dan $p$-value $=0.703>\alpha=$ 0,05 . Hasil ini menjelaskan bahwa variabel Ukuran Bank tidak berpengaruh terhadap risiko likuiditas. Hasil ini tidak mendukung hipotesis ketiga bahwa Ukuran Bank berpengaruh terhadap risiko likuiditas. Demikian juga, pada Model 2, Ukuran Bank menunjukkan nilai koefisien sebesar 0.003 dan $p$-value $=0.800>\alpha=0,05$. Nilai koefisien Ukuran Bank negatif dan tidak signifikan. Hasil ini juga tidak mendukung hipotesis ke ketiga yang menyatakan bahwa Ukuran Bank berpengaruh terhadap risiko likuiditas.

Hasil model 1, nilai koefisien Profitabilitas sebesar -0.044 dan $p$-value $=0.642>\alpha=$ 0,05 . Hasil ini menjelaskan bahwa variabel Profitabilitas tidak berpengaruh terhadap risiko 
likuiditas. Hasil ini tidak mendukung hipotesis keempat bahwa Ukuran Bank berpengaruh terhadap risiko likuiditas. Demikian juga, pada Model 2, Ukuran Bank menunjukkan nilai koefisien sebesar -0.128 dan $p$-value $=0.113>\alpha=0,05$. Nilai koefisien Profitabilitas negatif dan tidak signifikan. Hasil ini juga tidak mendukung hipotesis ke keempat yang menyatakan bahwa Ukuran Bank berpengaruh terhadap risiko likuiditas

Hasil model 1, nilai koefisien cadangan kerugian sebesar -0.589 dan $p$-value $=0.370>\alpha$ $=0,05$. Hasil ini menjelaskan bahwa variabel cadangan kerugian tidak berpengaruh positif terhadap risiko likuiditas. Hasil ini tidak mendukung hipotesis keempat bahwa cadangan kerugian berpengaruh terhadap risiko likuiditas. Demikian juga, pada Model 2, cadangan kerugian menunjukkan nilai koefisien sebesar -0.156 dan $p$-value $=0.855>\alpha=0,05$. Nilai koefisien cadangan kerugian negatif dan tidak signifikan. Hasil ini juga tidak mendukung hipotesis ke kelima yang menyatakan bahwa cadangan kerugian berpengaruh positif terhadap risiko likuiditas

Hasil model 1, menunjukkan bahwa nilai koefisien Cadangan Kas sebesar -1.271 dan $p$ value $=0.024<\alpha=0,05$. Hasil ini menjelaskan bahwa variabel Cadangan Kas berpengaruh negatif terhadap risiko likuiditas. Nilai koefisien negatif mengindikasikan jika kapitalisasi mengalami kenaikan, maka risiko likuiditas akan mengalami penurunan. Dengan kata lain Cadangan Kas berpengaruh negatif terhadap risiko likuiditas. Hasil ini tidak mendukung hipotesis keenam bahwa cadangan kas berpengaruh positif terhadap risiko likuiditas. Sementara itu, pada Model 2, Cadangan Kas menunjukkan nilai koefisien sebesar -1.838 dan $p$-value $=$ $0.012<\alpha=0,05$. Nilai koefisien Kapitalisasi menunjukkan arah negatif dan signifikan. Meskipun signifikan, hasil ini tidak mendukung hipotesis ke enam yang menyatakan bahwa Cadangan Kas berpengaruh positif terhadap risiko likuiditas.

Hasil model 1, menunjukkan bahwa nilai koefisien pinjaman atas deposan sebesar -0.388 dan $p$-value $=0.000<\alpha=0,05$. Hasil ini menjelaskan bahwa variabel pinjaman atas deposan berpengaruh negatif terhadap risiko likuiditas. Nilai koefisien negatif mengindikasikan jika kapitalisasi mengalami kenaikan, maka risiko likuiditas akan mengalami penurunan. Dengan kata lain Pinjaman atas deposan berpengaruh negatif terhadap risiko likuiditas. Hasil ini tidak mendukung hipotesis keenam bahwa Pinjaman atas deposan berpengaruh positif terhadap risiko likuiditas. Sementara itu, pada Model 2, Pinjaman atas deposan menunjukkan nilai koefisien sebesar -0.403 dan $p$-value $=0.000<\alpha=0,05$. Nilai koefisien Pinjaman atas deposan menunjukkan arah negatif dan signifikan. Meskipun signifikan, hasil ini tidak mendukung hipotesis ke enam yang menyatakan bahwa Pinjaman atas deposan berpengaruh positif terhadap risiko likuiditas.

\section{PEMBAHASAN}

Hasil penelitian baik pada model 1 dan model 2, kapitalisasi (cap) berpengaruh positif terhadap risiko likuiditas bank. Hasil ini mengindikasikan bahwa semakin tinggi kapitalisasi bank, maka semakin tinggi risiko likuiditas bank. Hasil ini juga menunjukkan bahwa kenaikan modal bank akan mengurangi masalah pada portofolio kredit dan dengan demikian akan meningkatkan rasio loan to deposit. Indriani (2008) juga menyatakan bahwa deposan harus mengasuransikan pinjamannya ketika mayoritas adalah deposan yang dapat mempengaruhi perubahan tingkat modal. Hasil penelitian konsisten dengan penelitian terdahulu (Deléchat, et al, 2012; Mehmed, 2014; Zolkifli, Hamidand, and Janor, 2015) menunjukkan bahwa kapitalisasi bank berpengaruh positif terhadap risiko kredit. Demikian juga, hasil penelitian konsisten dengan penelitian terdahulu oleh Deléchat (2012) dan Vodová (2013) yang menyatakan bahwa 
bank dengan kecukupan modal yang tinggi memiliki kecenderungan untuk lebih berhati-hati dan menyimpan lebih banyak cadangan likuiditas, sebab struktur modal yang baik mencerminkan manajemen risiko yang baik pula.

Hasil penelitian baik pada model 1 dan model 2, menunjukkan bahwa risiko kredit perusahaan tidak berpengaruh terhadap risiko likuiditas bank. Hasil mendukung penelitian Imbierowicz dan Rauch, (2014) dan Kumala (2016) menunjukkan bahwa risiko kredit tidak berpengaruh secara signifikan terhadap risiko likuiditas. Hal ini terjadi karena aset likuid berubah menjadi tidak likuid. Ghosh, (2015) berpendapat bahwa kenaikan NPL dalam portofolio pinjaman bank menyebabkan risiko lebih besar yang mempengaruhi likuiditas dan profitabilitas bank.

Demikian juga, hasil penelitian baik pada model 1 dan model 2, menunjukkan bahwa ukuran bank tidak berpengaruh terhadap risiko likuiditas bank. Hasil ini tidak mendukung penelitian sebelumnya bahwa ukuran bank berpengaruh terhadap risiko likuiditas bank (Deléchat,2012; Vodová, 2013). Hasil model 1 dan 2, menunjukkan bahwa profitabiltas bank tidak berpengaruh terhadap risiko likuiditas bank. Hasil ini tidak mendukung penelitian sebelumnya bahwa profitabiltas bank berpengaruh terhadap risiko likuiditas bank (Deléchat,2012; Vodová, 2013). Hasil model 1 dan 2, menunjukkan bahwa cadangan kerugian bank tidak berpengaruh terhadap risiko likuiditas bank. Meskipun demikian hasil penelitian tidak signifikan, arah hasil penelitian ini mendukung banyak penelitian terdahulu (Deléchat (2012), Mehmed (2014), Dinger (2009) dan Aspachs et al. (2005) yang menyatakan bahwa semakin tinggi profit yang dapat dihasilkan oleh bank, semakin rendah risiko Bank. Hubungan negatif ini dianggap terjadi karena semakin tinggi profitabilitas, semakin stabil dan mudah bagi bank untuk mengatur tingkat modal yang dibutuhkan apabila terjadi krisis sehingga bank dapat mengalokasikan profitnya untuk kegiatan ekonomi yang lebih menghasilkan. Hasil ini juga tidak mendukung penelitian sebelumnya bahwa cadangan kerugian berpengaruh terhadap risiko likuiditas bank (Deléchat,2012; Vodová, 2013).

Model 1 dan 2 juga menunjukkan bahwa cadangan kas berpangaruh negatif dan signifkan pada risiko likuiditas bank. Hasil ini tidak konsisten dengan penelitian sebelumnya, Mehmed (2014) menemukan bahwa cadangan kas berpengaruh positif terhadap risiko likuiditas. Demikian juga, hasil penelitian ini tidak konsisten dengan arah penelitian Indriani (2008) yang menemukan bahwa LD rendah akan menjamin bank dapat memenuhi penarikan yang besar dari deposan serta pinjaman tak terduga. Dengan demikian, LD memiliki hubungan positif dengan risiko likuiditas. Arah koefisien penelitian konsiten dengan penelitian Mehmed (2014) menemukan loan to deposit (LTD) berdampak negatif pada risiko likuiditas pada model 1, namun berdampak positif pada risiko likuiditas pada model 2. Model 1 dan 2 juga menunjukkan bahwa pinjaman atas deposan berpangaruh negatif dan signifkan pada risiko likuiditas bank. Arah pengaruh dari hasil penelitian menunjukkan arah negatif, sesuai dengan hipotesis. Artinya, semakin tinggi aset yang didanai nasabah, maka semakin kecil dana cadangan likuiditas yang dimiliki oleh bank. Hal ini menunjukkan manajemen risiko yang buruk dan melawan kesimpulan lain yang menyatakan semakin tinggi risiko, bank akan cenderung berhati-hati dan meningkatkan cadangan likuiditasnya. Namun mengingat kredit adalah aset, maka semakin tinggi proporsinya, proporsi aset lain yang mewakili cadangan likuiditas tentu akan semakin mengecil secara proporsional. Hasil regresi menunjukkan adanya pengaruh Profil Pendanaan Jangka Pendek terhadap Risiko likuiditas. Proporsi rata-rata yang hampir mendekati $80 \%$ menunjukkan kondisi bank yang sehat, dimana menurut peraturan dan standar pemerintah, kondisi tersebut terindikasi dari nilai rasio di atas $75 \%$ dan di bawah angka $85 \%$. Selain itu, 
kegiatan pendanaan kredit dengan menggunakan dana nasabah adalah salah satu kegiatan utama bank sehingga pertimbangan kondisi arus dana antar deposito dengan kredit akan sangat berpengaruh dan mendasari pengambilan keputusan atas manajemen risiko likuiditas bank.

\section{PENUTUP}

Berdasarkan hasil penelitian dan pembahasan, maka dapat disimpulkan bahwa semakin tinggi aset yang didanai oleh investor maka semakin tinggi cadangan likuiditas yang dimiliki oleh bank, dan semakin tinggi aset yang didanai oleh nasabah maka semakin rendah cadangan likuiditas yang dimiliki oleh bank. Oleh karenanya, dapat disimpulkan bahwa bank di Indonesia memiliki kecenderungan untuk mengatur risiko likuiditasnya dengan meningkatkan aset yang didanainya sendiri. Struktur modal yang banyak didanai oleh dana investor dan bukan oleh liabilitas menunjukkan manajemen risiko yang baik dan menunjukkan tingkat cadangan likuiditas yang baik pula.

\section{REFERENSI}

Aspachs, O. E. Nier, Tiesset, M., 2005. Liquidity, Banking Regulation and the Macroeconomics, Evidence on bank liquidity holdings from a panel of UK-resident banks, $B I S$.

Belaid, F., Bellouma, M., and Omri, Abd. 2016. Determinants of Liquidity Risk: Evidence from Tunisian Banks. International Journal of Emerging Research in Management \& Technology, 5, 6

Chaplin, G.; Emblow, A.; Michael, I. 2000. Banking system li- quidity: developments and issues, Financial Stability Review, p. 93-112.

Diamond, D. W.; Rajan, R. G. 2001. Liquidity risk, liquidity creation, and financial fragility: a theory of banking, The Journal of Political Economy,109,2,p. 287-327.

Deléchat, C., Henao, C. Muthoora, P., Vtyurina, S., 2012. The Determinants of Banks' Liquidity Buffers in Central America", IMF Working Paper

Dinger, V.,(2009. Do Foreign-owned Banks Affect Banking System Liquidity Risk? . Journal of Comparative Economics, 37.

Farag, M., Harland, D., Nixon, D., 2013.Bank Capital and Liquidity, Quarterly Bulletin, Bank of England, Q3.

Goddard, J.; Molyneux, P.; Wilson, J. O. 2009. The financial crisis in Europe: evolution, policy responses and lessons for the fu ture, Journal of Financial Regulation and Compliance 17,4, p $362-380$

Ghosh, A., 2015. Banking-industry specific and regional economic determinants of NonPerforming Loans: Evidence from US States, Journal of Financial Stability, 20, p. 93$104,2015$.

Hawawini, G.; Vialler, C. 2007. Finance for executives managing for value creation. 3rd ed. South - Western Pub Ltd. 672 p.

Holmstrom, B., Tirole, J., 1998. Private and Public Supply of Liquidity, Journal of Political Economy, University of Chicago Press, 106.

Kiyotaki, N., and Moore, J. H., 2008. Liquidity, Business Cycles and Monetary Policy, Princeton University, Edinburgh University and London School of Economics.

Imbierowicz, B., and Rauch, C. 2014. The relationship between liquidity risk and credit risk in banks", Journal of Banking and Finance, 40, p. 242-256. 
Indriani, V 2008. The Relationship Between Islamic Financing With Risks And Performance of Commercial Banks In Indonesia, Master thesis, University of Malaya

Kumala, I. 2016. Karakteristik Perbankan Pada Cadangan Likuiditas Bank Swasta Nasional Devisa Di Indonesia. Skripsi, Fakultas Bisnis, UKDW

Jenkinson, N. 2008. Strengthening regimes for controlling liquidity risk, Euro Money Conference on Liquidity and Funding Risk Management, Bank of England, London, p. 9.

Kiyotaki, N., Moore, J. H. (2008), "Liquidity, Business Cycles and Monetary Policy, "Princeton University, Edinburgh University and London School of Economics

Louzis, D., Vouldis, A., Metaxas, V., 2012. Macroeconomic and bank-specific determinants of non-performing loans in Greece: A comparative study of mortgage, business and consumer loan portfolios. Journal of Banking \& Finance, 36, p. 1012-1027

Mehmed, G., 2014. An Empirical Study on Liquidity Risk and Its Determinants in Bosnia and Herzegovina. Ther Romanian Economic Journal, 17,5.

Zolkifli, N.A., Hamidand, M.A., and Janor, H. 2015. Liquidity Risk and Performance: The Case of Bahrain and Malaysian Banks. Global Economy and Finance Journal, 8, 2, p. 95 - 111

Sawada, M, 2010 Liquidity Risk and Bank Portfolio Management in a Financial System without Deposit Insurance: Empirical Evidence from Pre-war Japan, International Review of Economics and Finance, 19,3, p.392-406

Siddiqi, N. 2008. Current financial crisis and Islamic economics. Available from Internet: http://www.siddiqi.com/mns/

Sohaimi, A.N.A., 2013. Liquidity Risk and Performance of Banking System in Malaysia, Mara University of Technology Johor, Malaysia.

Vodova, P., 2013.Determinants Which Affect Liquid Asset Ratio of Czech and Slovak Commercial Banks, 1.

Roman, A. and Sargu, A., C.,2015. The impact of bank-specific factors on the commercial banks liquidity: empirical evidence from CEE countries. Procedia Economics and Finance, 20, p. 571 - 579, 2015

Zaghdoudi, K and Hakimi, A. .2017. The Determinants of Liquidity Risk: Evidence from Tunisian Banks. Journal of Applied Finance \& Banking, 7, 2, p. 71-81 